\title{
PENYUSUNAN STRATEGI PEMBANGUNAN SISTEM PENYEDIAAN AIR MINUM (SPAM) KOTA DUMAI DENGANMENGGUNAKAN AHP (ANALYTICAL HIERARCHY PROCESS)
}

\author{
Riau Satrya Alamsyah, Manyuk Fauzi dan Ari Sandhyavitri \\ Jurusan Teknik Sipil, Fakultas Teknik, Universitas Riau, Pekanbaru \\ E-mail : riau_alamsyah@yahoo.co.id
}

\begin{abstract}
ABSTRAK
Kota Dumai yang berada di Provinsi Riau merupakan Kota yang pelayanan air minumnya masih sangat rendah. Beberapa upaya yang dilakukan pemerintah kota untuk meningkatkan pelayanan air minum kemasyarakat tetapi belum berhasil. Penelitian ini melakukan kajian bagaimana strategi yang tepat untuk pembangunan Sistem Penyediaan Air Minum (SPAM) Kota Dumai dengan menggunakan dengan menggunakan AHP (Analytical Hierarchy Process). Para ahli (expert)yang menjadi responden adalah pembuat kebijakan, pelaku, konsultan dan tenaga ahli yang terlibat langsung pada pembangunan SPAM Kota Dumai.Metoda yang digunakan pada penelitian ini adalah metoda pembobotan (Scoring Method) dan AHP dengan menggunakan perangkat lunak Expert Choice 2000. Penilaian kesiapan Kota Dumai pada pembangunan SPAM Kota Dumai dan identifikasi kriteria-kriteria dan sub kriteria signifikan Pembangunan SPAM Kota Dumai dengan menggunakan metoda pembobotan. Hasil dengan menggunakan Expert Choice 2000 kriteria yang paling berpengaruh dalam pembangunan SPAM Kota Dumai adalah kriteria lingkungansebesar 37,1\% , kriteria kepemimpinan dan SDM sebesar 24,2\% serta kriteria teknis sebesar 16,9\%. Dari ketiga kriteria yang paling berpengaruh tersebut dikembangkan 10 strategi pembangunan SPAM Kota Dumai yang kemudian dilanjutkan dengan menyebarkan kuisioner kembali kepada para ahli dan dengan menggunakan Expert Choice 2000 didapatkan urutan prioritas kesepuluh strategi pembangunan SPAM Kota Dumai adalah optimalisasi IPA Sudirman 28,7\%, melanjutkan pembangunan jaringan pipa tahun 2008-2011 $20,4 \%$, pembangunan fasilitas dan utilitas di lokasi off take SPAM Regional $14,4 \%$, penyesuaian tarif air minum $11,2 \%$, pembangunan intake dan bendung Sungai Mesjid 7,3\%, pembangunan IPA baru 5,9\%, penyertaan modal kembali ke PDAM, peningkatan kualitas SDM PDAM 3,5\%, pembangunan SPAM embung dan pemanfaatan IPA RO $80 \mathrm{~L} / \mathrm{dtk}$ 1,8\%. Kesepuluh strategi ini yang kemudian dimasukkan kedalam rentang waktu program jangka menengah 5 tahunan yang kemudian dijabarkan lagi dengan program dan kegiatan tiap tahun.
\end{abstract}

Kata Kunci: AHP, Expert Choice 2000, and SPAM 


\begin{abstract}
Dumai city is located in Riau Province. It's a city with people access rate to drinking water services is still low at $32.51 \%$. Several efforts by the local government to improve drinking water services to the community has been done, but with less success. This research is to find out how is the right strategy for development of Water Supply System by using AHP (Analytical Hierarchy Process). Experts who are respondents in this study are policy makers, actors, consultants and experts who are directly involved in Dumai City water supply development. The AHP method using the Expert Choice 2000 application is used to determine the criteria and sub criteria of the most influential water supply development and determine the priority for water supply development strategy. The result by using Expert Choice 2000 the most influential criteria in water supply development is environmental with $37,1 \%$, leadership and human resources $24,2 \%$ and technical matters 16,9\%. From top three most influential criteria, were developed into 10 strategies water supply development which then questioned with questionnaire to the experts using Expert Choice 2000 to prioritize the order of 10th prioritywater supply strategy are: WTP Sudirman optimization 28,7\%, construction of pipelines plan in 2008-2011 20.4\%, construction of facilities and utilities at off take locations Water supply Regional DUROLIS 14.4\%, adjustment of tariffs for water supply services 11.2\%, construction of intake and dam of Mesjidriver $7.3 \%$, construction of new WTP $5.9 \%$, capital investment to PDAMand improvement of quality of PDAM 3.5\% human resources, water supply system Dam development and utilization of IPA RO $80 \mathrm{~L} / \mathrm{sec} 1.8 \%$. These ten strategies are then incorporated into the 5-year period of the 5 year mediumterm program which is further elaborated with programs and activities annually.
\end{abstract}

Keywords: AHP, Expert Choice 2000, and SPAM,

\title{
PENDAHULUAN
}

Kota Dumai memiliki cakupan pelayanan air minum yang rendah, 32,51\% (Data Dinkes Kota Dumai Tahun 2017) rumah tangga dengan akses air minum layak dan baru $3 \%$ sambungan rumah yang merupakan jaringan perpipaan dari PDAM.Permasalahan SPAM di Kota Dumai tidak hanya ada pada masalah teknis seperti air baku, jaringan dan IPA tetapi juga permasalahan kelembagaan PDAM yang berkinerja tidak baik. Pemerintah Kota Dumai telah pernah berupaya dengan pembangunan SPAM tahun 2008-2011 dengan pembangunan jaringan perpipaan HDPE dan IPA RO tetapi sampai saat ini belum bisa dimanfaatkan karena pembangunan tersebut tidak terselesaikan. 
Sejak tahun 2015 telah diinisiasi program pembangunan SPAM Regional Durolis (Dumai, Rokan Hilir dan Bengkalis) dengan sumber air baku berasal Sungai Rokan.Berdasarkan kesepakatan bersama dan perjanjian kerjasama tersebut SPAM Regional Durolis akan dibangun dengan kapasitas intake 1650 1/dtk dengan kapasitas IPA 1500 l/dtk melalui 4 (empat) tahap pembangunan yang dilaksanakan dari tahun 2017 sampai dengan tahun 2030 dengan sistem pemberian air curah kepada kabupaten/kota. Kota Dumai mendapatkan 500 l/dtk dengan tahap I pada tahun 2020150 l/dtk. Kewajiban Pemerintah Kota Dumai dalam rangka kerjasama SPAM Regional adalah menyiapkan jaringan distribusi dari lokasi off take ke wilayah pelayanan di Kota Dumai.

Melihat kondisi tersebut di atas maka diperlukan suatu strategi yang jelas terhadap kelanjutan pembangunan air minum di Kota Dumai. Adapun tujuan dari penelitian ini adalah:

1. Penilaian pra kondisi Kota SPAM Kota Dumai

2. Identifikasi kriteria-kriteria signifikan di dalam pembangunan sistem penyediaan air minum (SPAM) di Kota Dumai.

3. Menganalisis kriteria signifikan yang digunakan untuk menentukan prioritas dalam pembangunan sistem penyediaan air minum di Kota Dumai.

4. Menyusun strategi jangka menengah pembangunan sistem penyediaan air minum di Kota Dumai.

\section{STUDI PUSTAKA}

Studi pustaka dilakukan untuk memperoleh dasar teori yang jelas mengenai permasalahan SPAM dan kriteria-kriteria yang terkait dalam pembangunan SPAM. Teori-teori bersumber dari buku, jurnal dan penelitian yang terkait dengan penelitian yang akan dilaksanakan. Berdasarkan hasil studi pustaka Parameter direncanakan didasarkan pada tujuh kriteria yang dibagi menjadi:

1. Kriteria Pranata Hukum dan Kebijakan

a. dasar hukum perundang-undangan dan perangkat hukum di bawahnya untuk sektor air minum.

b. kebijakan dan rencana Pemerintah terhadap sektor Air Minum

c. kebijakan pemerintah Provinsi Riau sektor air minum

d. kebijakan pemerintah kota Dumai di sektor air minum

2. Kriteria Teknis Pembangunan SPAM

a. mutu air baku

b. mutu air produksi

c. waduk atau long storage untuk penyimpanan air

d. jarak sumber air baku dengan wilayah pelayanan

e. kondisi infrastruktur air minum di up stream (Hulu)

f. kondisi Infrastruktur air minum di dawn stream (Hilir)

g. laju kebutuhan air minum

h. jenis teknologi pengolahan air

3. Kriteria Keuangan pada Pembangunan SPAM

a. biaya pra pembangunan infrastruktur air minum 

b. biaya konstruksi
c. biaya operasional dan pemeliharaan
d. sumber dana penyelenggaraan SPAM
e. harga jual air

4. Kriteria Lingkungan
a. kondisi geografi dan demografi
b. ketersediaan air baku
c. kapasitas air baku
d. kualitas air baku
e. klimatologi
f. kondisi air tanah
g. perubahan guna lahan

5. Kriteria Sosial, ekonomi dan budaya masyarakat mempengaruhi pembangunan SPAM
a. kepedulian masyarakat dan keterlibatan masyarakat
b. tingkat keinginan untuk menyambung (willingness to connect)
c. willingness to pay (WTP) masyarakat kota Dumai
d. prilaku masyarakat

6. Kriteria Kelembagaan dalam mendukung pembangunan SPAM
a. kelembagaan dan pengelolaan keuangan
b. kehilangan air
c. kerja sama antara pemerintah dengan pemerintah daerah, dan kerja sama antar pemerintah daerah
d. kerja sama pemerintah dengan badan usaha
e. kerjasama antar badan usaha

7. Kriteria Sumber Daya Manusia
a. komitmen pimpinan
b. kualitas SDM pengelola SPAM
c. jumlah pegawai pengelola SPAM
d. kurangnya kesadaran pemerintah terhadap pembiayaan penyediaan air minum perkotaan yang berkelanjutan
e. visi dan misi pimpinan daerah

\section{METODA PENELITIAN}

Lokasi penelitian adalah Kota Dumai provinsi Riau yang dapat digambarkan pada gambar 1 sebagai berikut:

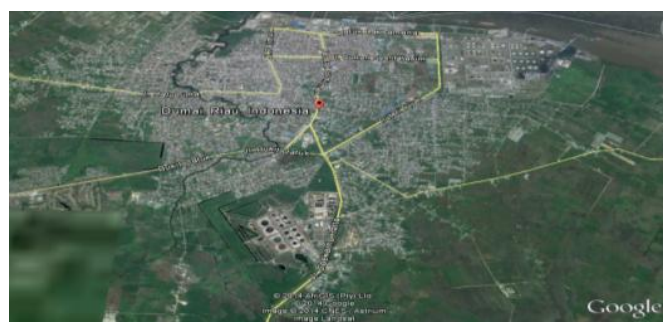

Gambar 1 Lokasi Penelitian 
Metoda yang digunakan adalah metoda pembobotan kartu (Scoring card Method) untuk penilain pra kondisi SPAM Kota Dumai dan identifikasi kriteriakriteria signifikan pembangunan SPAM Kota Dumai.Sedangkan untuk menentukan prioritas kriteria-kriteria signifikan dan prioritas strategi jangka menengah Pembangunan SPAM Kota Dumai menggunakan AHP (Analytical Hierarchy Process) dengan perangkat lunak Expert Choice 2000. Penggunaan AHP pada studi penelitian ini dikarenakan model yang dikembangkan oleh Thomas L. Saaty, dapat memecahkan masalah yang kompleks, dimana aspek dan kriteria yang diambil cukup banyak. Menurut Saaty (1993), skala penilaian 1 sampai 9 merupakan yang terbaik berdasarkan nilai RMS (Root Mean Square Deviation) dan MAD (Median Absolute Deviation). Nilai dan definisi pendapat kualitatif tersebut dapat dilihat pada Tabel 1.

\section{Tabel 1 Skala Komparasi Pada PenilaianAHP}

\begin{tabular}{|c|l|}
\hline $\begin{array}{c}\text { Tingkat } \\
\text { Kepentingan }\end{array}$ & \multicolumn{1}{c|}{ Definisi } \\
\hline 1 & Sama pentingnya \\
\hline 3 & Sedikit lebih penting \\
\hline 5 & Jelas lebih penting \\
\hline 7 & Sangat jelas lebih penting \\
\hline 9 & Mutlak lebih penting \\
\hline $2,4,6,8$ & $\begin{array}{l}\text { Apabila ragu-ragu antara dua } \\
\text { nilai yang berdekatan }\end{array}$ \\
\hline $1 /(1-9)$ & $\begin{array}{l}\text { Kebalikan nilai tingkat } \\
\text { kepentingan dari skala } 1 \text { - } 9\end{array}$ \\
\hline
\end{tabular}

(Sumber : Saaty, 1993)

Terdapat empat tahapan analisa penelitian dengan waktu yang berurutan yaitu:

1. Tahap I berdasarkan survei kuisioner Pra kondisi dilakukan analisa pembobotan untuk menentukan kriteria-kriteria signifikan Pembangunan SPAM Kota Dumai.

2. Tahap IIberdasarkan survei kuisioner kriteria SPAMdilakukan analisis pembobotan untuk mengidentifikasi kriteria-kriteria dalam penyusunan strategi pembangunan SPAM Kota Dumai.

3. Hasil dari identifikasi kriteria-kriteria pada tahap II menjadi bahan survei pada tahap III dan hasil survei responden tahap III dianalisis dengan menggunakan perangkat lunakExpert Choice 2000menghasilkan kriteria-kriteria signifikan dalam penyusunan strategi pembangunan SPAM Kota Dumai.

Hasil dari tahap III dijabarkan menjadi strategi-strategi pembangunan SPAM Kota Dumai. Strategi itu menjadi bahan survei responden tahap IV yang selanjutnya hasil survei akan dianalisis melalui Expert Choice 2000 dan akan menghasilkan urutan prioritas strategi pembangunan SPAM Kota Dumai. Strategi tersebut disusun dalam jangka menengah dan masing-masing strategi dijabarkan dalam bentuk program dan kegiatan per tahun selama 5 (lima) tahun. 


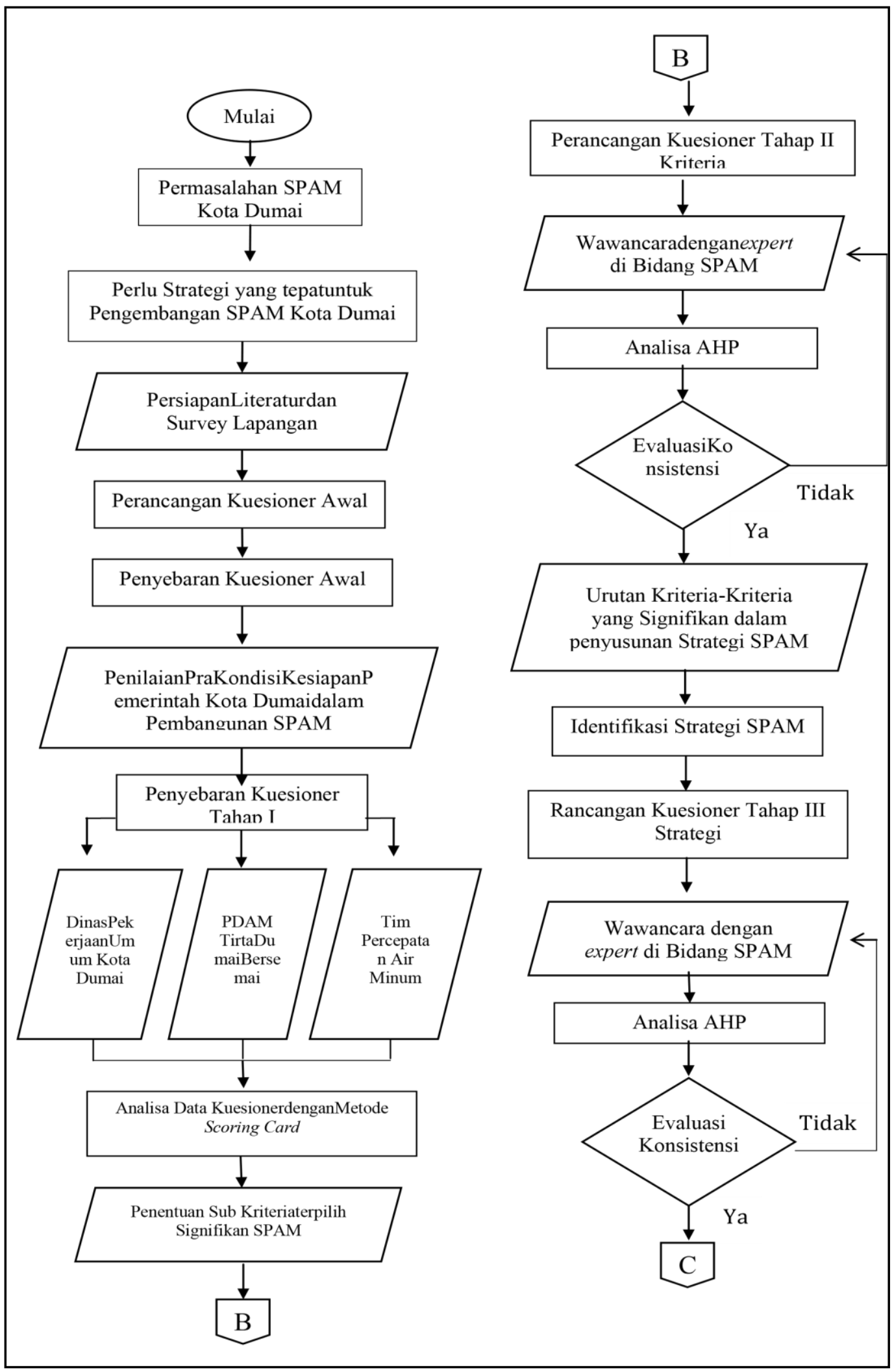

Gambar 2. Kerangka Pikir 


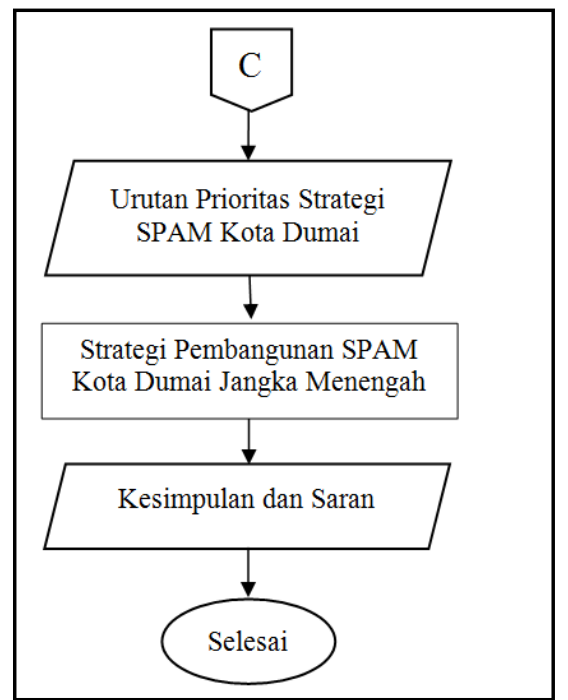

Gambar 2. lanjutan Kerangka Pikir

\section{PRA KONDISI SPAM KOTA DUMAI}

Penilaian dilakukan survei langsung dengan menggunakan kuesioner kepadaKepala Dinas Pekerjaan Umum Kota Dumai. Kuesioner memberikan pertanyaan terkait kesiapan pembangunan SPAM Kota Dumai terhadap parameter kriteria yang ada. Dengan menggunakanScoring Card Methodpenilaiannya adalah sebagai berikut:

Nilai $1=$ Tidak Siap

$2=$ Kurang Siap

$3=$ Siap

$4=$ Sangat Siap

Tabel 2 Hasil Kuesioner Pra Kondisi Pembangunan Insfrastruktur Air Minum Kota Dumai

\begin{tabular}{|c|c|c|c|c|c|c|}
\hline \multirow[t]{2}{*}{ NO } & \multirow{2}{*}{$\begin{array}{c}\text { Parameter Strategi Pembangunan Air } \\
\text { Minum }\end{array}$} & \multicolumn{4}{|c|}{$\begin{array}{c}\text { KESIAPAN } \\
\text { PEMBANGUNAN } \\
\text { SPAM } \\
\end{array}$} & \multirow{2}{*}{$\frac{\text { ВОВОТ }}{5}$} \\
\hline & & 1 & 2 & 3 & 4 & \\
\hline & $\begin{array}{l}\begin{array}{l}\text { Kriteria } \\
\text { Kebijakan }\end{array}\end{array}$ & & & & & \\
\hline 1 & $\begin{array}{l}\text { Dasar Hukum Perundang-undangan dan } \\
\text { perangkat hukum di bawahnya untuk } \\
\text { sektor air minum }\end{array}$ & & & & $\checkmark$ & 4 \\
\hline 2 & $\begin{array}{lll}\text { Kebijakan dan rencana } & \text { Pemerintah } \\
\text { terhadap sektor Air Minum } & \\
\end{array}$ & & & & $\checkmark$ & 4 \\
\hline 3 & $\begin{array}{lll}\begin{array}{l}\text { Kebijakan Pemerintah } \\
\text { Sektor Air Minum }\end{array} & \text { Provinsi } & \text { Riau } \\
\end{array}$ & & & & $\checkmark$ & 4 \\
\hline 4 & $\begin{array}{l}\text { Kebijakan Pemerintah Kota Dumai di } \\
\text { Sektor Air Minum }\end{array}$ & & & & $\checkmark$ & 4 \\
\hline & Kesiapan & & & & & 4 \\
\hline & Kriiteria Teknis & & & & & \\
\hline 5 & Mutu Air Baku & & $\checkmark$ & & & 2 \\
\hline
\end{tabular}




\begin{tabular}{|c|c|c|c|c|c|c|}
\hline 6 & Mutu Air Produksi & & $\checkmark$ & & & 2 \\
\hline 7 & 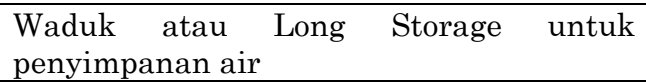 & $\checkmark$ & & & & 1 \\
\hline 8 & $\begin{array}{l}\text { Jarak Sumber Air Baku dengan Wilayah } \\
\text { Pelayanan }\end{array}$ & & $\checkmark$ & & & 2 \\
\hline 9 & $\begin{array}{l}\text { Kondisi Infrastruktur air Minum di Up } \\
\text { Stream (Hulu) }\end{array}$ & & $\checkmark$ & & & 2 \\
\hline 10 & $\begin{array}{l}\text { Kondisi Infrastruktur air Minum di Dawn } \\
\text { Stream (Hilir) }\end{array}$ & $\checkmark$ & & & & 1 \\
\hline 11 & Laju Kebutuhan Air & & & $\checkmark$ & & 3 \\
\hline \multirow[t]{3}{*}{12} & Jenis Teknologi Pengolahan Air & & & $\checkmark$ & & 3 \\
\hline & Kesiapan & & & & & 2 \\
\hline & Kriteria Keuangan & & & & & \\
\hline 13 & $\begin{array}{l}\text { Biaya Pra Pembangunan Infrastruktur } \\
\text { Air Minum }\end{array}$ & & & $\checkmark$ & & 3 \\
\hline 14 & Biaya Konstruksi & & & $\checkmark$ & & 3 \\
\hline 15 & Biaya Operasional dan Pemeliharaan & & & $\checkmark$ & & 3 \\
\hline 16 & Sumber Dana Penyelenggaraan SPAM & & & $\checkmark$ & & 3 \\
\hline \multirow[t]{3}{*}{17} & Harga Jual Air & $\checkmark$ & & & & 1 \\
\hline & Kesiapan & & & & & 2.6 \\
\hline & Kriteria Lingkungan & & & & & \\
\hline 18 & Kondisi Geografi dan Demografi & & $\checkmark$ & & & 2 \\
\hline 19 & Ketersediaan air baku & $\checkmark$ & & & & 1 \\
\hline 20 & Kapasitas air baku & & $\checkmark$ & & & 2 \\
\hline 21 & Kualitas air baku & $\checkmark$ & & & & 1 \\
\hline 22 & Klimatologi & & & $\checkmark$ & & 3 \\
\hline 23 & Kondisi Air Tanah & & $\checkmark$ & & & 2 \\
\hline \multirow[t]{3}{*}{24} & Perubahan Guna lahan & & & $\checkmark$ & & 3 \\
\hline & Kesiapan & & & & & 2.00 \\
\hline & $\begin{array}{l}\text { Kriteria Sosial, ekonomi dan Budaya } \\
\text { masyarakat }\end{array}$ & & & & & \\
\hline 25 & $\begin{array}{l}\text { Kepedulian Masyarakat dan keterlibatan } \\
\text { Masyarakat }\end{array}$ & & & $\checkmark$ & & 3 \\
\hline 26 & $\begin{array}{l}\text { Tingkat Keinginan untuk menyambung } \\
\text { (Willingness To Connect) }\end{array}$ & & & $\checkmark$ & & 3 \\
\hline 27 & $\begin{array}{l}\text { Willingness To Pay (WTP) masyarakat } \\
\text { Kota Dumai }\end{array}$ & & & & $\checkmark$ & 4 \\
\hline \multirow[t]{3}{*}{28} & Prilaku masyarakat & & & $\checkmark$ & & 3 \\
\hline & Kesiapan & & & & & 3.25 \\
\hline & Kriteria Kelembagaan & & & & & \\
\hline 29 & Kelembagaan dan Pengelolaan Keuangan & & $\checkmark$ & & & 2 \\
\hline 30 & Kehilangan Air & $\checkmark$ & & & & 1 \\
\hline 31 & $\begin{array}{l}\text { Kerjasama antara Pemerintah dengan } \\
\text { Pemerintah Daerah, dan Kerjasama antar } \\
\text { Pemerintah Daerah }\end{array}$ & & & & $\checkmark$ & 4 \\
\hline
\end{tabular}




\begin{tabular}{|c|l|c|c|c|c|c|}
\hline 32 & $\begin{array}{l}\text { Kerjasama Pemerintah dengan badan } \\
\text { usaha }\end{array}$ & & & $\checkmark$ & & 3 \\
\hline 33 & Kerjasama Antar Badan Usaha & & & $\checkmark$ & & 3 \\
\hline & $\begin{array}{l}\text { Kesiapan } \\
\text { Kepemimipinan }\end{array}$ & & & & & $\mathbf{2 . 6}$ \\
\hline 34 & Komitmen Pimpinan & & & $\checkmark$ & & 3 \\
\hline 35 & Kualitas SDM pengelolaa SPAM & & $\checkmark$ & & & 2 \\
\hline 36 & $\begin{array}{l}\text { Jumlah Pegawai Pengelolaan SPAM } \\
\text { Kurangnya Kesadaran Pemerintah } \\
\text { Daerah Terhadap pembiayaan Penyediaan } \\
\text { air minum perkotaan yang berkelanjutan }\end{array}$ & & $\checkmark$ & & & 2 \\
\hline
\end{tabular}

\begin{tabular}{|ll|}
\hline \multicolumn{2}{|l|}{ Keterangan : } \\
\hline Nilai Bobot \\
1 & $=$ Tidak Siap \\
\hline 2 & $=$ Kurang Siap \\
\hline 3 & $=$ Siap \\
\hline 4 & $=$ Sangat Siap \\
\hline
\end{tabular}

\begin{tabular}{|lc|l|}
\hline \multicolumn{2}{|l|}{ Interval Kesiapan } \\
I & $1-1,999$ & $=$ Tidak siap \\
\hline II & $2-2,99$ & $=$ Kurang Siap \\
\hline III & $3-3,99$ & $=$ Siap \\
\hline IV & 4 & $=$ Sangat siap \\
\hline
\end{tabular}

\section{IDENTIFIKASI KRITERIA SIGNIFIKAN}

Survei dilakukan dengan menyebarkan 10 kuesioner kepada 4 instansi yaitu Dinas Pekerjaan Umum Kota Dumai, BAPPEDA Kota Dumai, PDAM Tirta Dumai Bersemai Kota Dumai, Sekolah Tinggi Teknologi Kota Dumai, Tim Percepatan Pembangunan Infrastruktur Air Minum Kota Dumai. Dari 10 kuesioner yang disebarkan kepada masing-masing instansi.Kumpulan data kuesioner dianalisisdengan menggunakan metoda pembobotan kartu, yaitu perkalian terhadap tingkat pengaruh dengan jumlah pilihan. Untuk masing-masing kriteria dipilih 4 sub kriteria yang terbesar. Hasil pembobotan dapat dilihat pada Tabel 2

\section{PENENTUAN KRITERIA PRIORITAS}

Survei dilakukan dengan menyebarkan 5 kuesioner kepada 3 instansi yaitu Dinas Pekerjaan Umum Kota Dumai, Dinas Pekerjaan Umum dan Tata Ruang Provinsi Riau, Bappeda Kota Dumai dan Tenaga Ahli Air Minum Dinas PUPR Kota Dumai. Langkah awal dalam analisa ini adalah memasukkan nilai kriteria-kriteria yang ada dalam kuesioner detail, yaitu: pranata hukum,teknis, keuangan, lingkungan, sosial ekonomi budaya, kelembagaan dan kepemimpinan ke dalam aplikasi Expert Choice 2000. Misalnya: Pranata Hukum vs Teknis $=5$ 
Tabel 2 Hasil Pembobotan Kriteria Signifikan Dalam Pengambilan Keputusan Penvusunan Strategi Penvediaan Air Minum di Kota Dumai

\begin{tabular}{|c|c|c|c|c|c|c|}
\hline \multirow[t]{2}{*}{ NO } & \multirow[t]{2}{*}{ Parameter Strategi Pembangunan Air Minum } & \multicolumn{4}{|c|}{$\begin{array}{c}\text { Tingkat Pengaruh Kriteria } \\
\text { Signifikan Dakm Pengambilan } \\
\text { Keputusan Penyusunan Strategi } \\
\text { Penyediaan Air Minum Kota Dumai }\end{array}$} & \multirow[t]{2}{*}{ SKOR } \\
\hline & & $\mathbf{1}$ & $\mathbf{2}$ & 3 & 4 & \\
\hline $\mathbf{I}$ & Kriteria Pranata Hukum dan Kebijakan & & & & & \\
\hline $\mathbf{1}$ & $\begin{array}{l}\text { Dasar Hukum Perundang-undangan dan perangkat hukum di bawahnya } \\
\text { untuk sektor air minum }\end{array}$ & & & 1 & 9 & 39 \\
\hline 2 & Kebijakan dan rencana Pemerintah terhadap sektor Air Minum & & & $\mathbf{1}$ & 9 & 39 \\
\hline 3 & Kebijakan Pemerintah Kota Dumai di Sektor Air Minum & & & $\mathbf{1}$ & 9 & 39 \\
\hline 4 & Kebijakan Pemerintah Provinsi Riau Sektor Air Minum & & $\mathbf{1}$ & 4 & 5 & 34 \\
\hline II & Kriteria Teknis & & & & & \\
\hline $\mathbf{1}$ & Mutu Air Baku & & $\mathbf{1}$ & 4 & 5 & 34 \\
\hline 2 & Jenis Teknologi Pengolahan Air & & $\mathbf{1}$ & 4 & 5 & 34 \\
\hline 3 & Jarak Sumber Air Baku dengan Wilayah Pelayanan & & & 7 & 3 & 33 \\
\hline 4 & Mutu Air Produksi & & & 7 & 3 & 33 \\
\hline 5 & Kondisi Infrastruktur air Minum di Up Stream (Hulu) & & $\mathbf{1}$ & 6 & 3 & 32 \\
\hline 6 & Laju Kebutuhan Air & & 2 & 4 & 4 & 32 \\
\hline 7 & Kondisi Infrastruktur air Minum di Down Stream (Hilir) & & 2 & 5 & 3 & 31 \\
\hline 8 & Waduk atau Long Storage untuk peryimpanan air & $\mathbf{1}$ & 3 & 4 & 2 & 27 \\
\hline III & Kriteria Keuangan & & & & & \\
\hline $\mathbf{1}$ & Biaya Konstruksi & & & 4 & 6 & 36 \\
\hline 2 & Sumber Dana Penyelenggaraan SPAM & & & 4 & 6 & 36 \\
\hline 3 & Harga Jual Air & & $\mathbf{1}$ & 3 & 6 & 35 \\
\hline 4 & Biaya Operasional dan Pemeliharaan & & & 7 & 3 & 33 \\
\hline 5 & Biaya Pra Pembangunan Infrastruktur Air Minum & & 3 & 5 & 2 & 29 \\
\hline
\end{tabular}

\begin{tabular}{|c|c|c|c|c|c|c|}
\hline $\mathbf{I V}$ & Kriteria Lingkungan & & & & & \\
\hline 1 & Ketersediaan air baku & & & 3 & 7 & 37 \\
\hline 2 & Kapasitas air baku & & & 4 & 6 & 36 \\
\hline 3 & Klimatologi & & & 5 & 5 & 35 \\
\hline 4 & Kualitas air baku & & 1 & 8 & $\mathbf{1}$ & 30 \\
\hline 5 & Kondisi Geografi dan Demografi & & 3 & 6 & $\mathbf{1}$ & 28 \\
\hline 6 & Perubahan Guna lahan & & 3 & 7 & & 27 \\
\hline 7 & Kondisi Air Tanah & $\mathbf{1}$ & 4 & 4 & $\mathbf{1}$ & 25 \\
\hline $\mathbf{V}$ & Kriteria Sosial, ekonomi dan Budaya masyarakat & & & & & \\
\hline $\mathbf{1}$ & Willingness To Pay (WTP) masyarakat Kota Dumai & & & 5 & 5 & 35 \\
\hline 2 & Tingkat Keinginan untuk menyambung (Willingness To Connect) & & & 6 & 4 & 34 \\
\hline 3 & Kepedulian Masyarakat dan keterlibatan Masyarakat & & & $\mathbf{8}$ & 2 & 32 \\
\hline 4 & Prilaku masyarakat & & 2 & 7 & $\mathbf{1}$ & 29 \\
\hline $\mathbf{V I}$ & Kriteria Kelembagaan & & & & & \\
\hline $\mathbf{1}$ & Kerjasama Antar Badan Usaha & & & 2 & $\mathbf{8}$ & 38 \\
\hline 2 & Kelembagaan dan Pengelolaan Keuangan & & & 5 & 5 & 35 \\
\hline 3 & Kehilangan Air & & & 6 & 4 & 34 \\
\hline 4 & $\begin{array}{l}\text { Kerjasama antara Pemerintah dengan Pemerintah Daerah, dan } \\
\text { Kerjasama antar Pemerintah Daerah }\end{array}$ & & & 8 & 2 & 32 \\
\hline 5 & Kerjasama Pemerintah dengan badan usaha & & 2 & 7 & $\mathbf{1}$ & 29 \\
\hline VII & Kriteria Sumber Daya Manusia dan Kepemimipinan & & & & & \\
\hline $\mathbf{1}$ & Komitmen Pimpinan & & & $\mathbf{1}$ & 9 & 39 \\
\hline 2 & Visi dan Misi Pimpinan Daerah & & & 1 & 9 & 39 \\
\hline 3 & $\begin{array}{l}\text { Kurangnya Kesadaran Pemerintah Daerah Terhadap pembiayaan } \\
\text { Penyediaan air minum perkotaan yang berkelanjutan }\end{array}$ & & & 3 & 7 & 37 \\
\hline 4 & Kualitas SDM pengelolaa SPAM & & & 6 & 4 & 34 \\
\hline 5 & Jumlah Pegawai Pengelolaan SPAM & & $\mathbf{1}$ & 7 & 2 & 31 \\
\hline
\end{tabular}

(kriteria teknis jelas lebih penting daripada kriteria pranata hukum), Keuangan vs Lingkungan $=7$ (kriteria lingkungan sangat jelas lebih penting daripada kriteria keuangan), dan Kelembagaan vs Kepemimpinan $=3$ (kriteria 
kepemimpinan sedikit lebih penting daripada kriteriakelembagaan).Setelah memasukkan hasil responden tersebut akan dapat diketahui seberapa persen pentingnya tiap kriteria-kriteria tersebut dengan melihat dynamic sensitivity seperti yang terlihat pada Gambar 3 berikut ini:

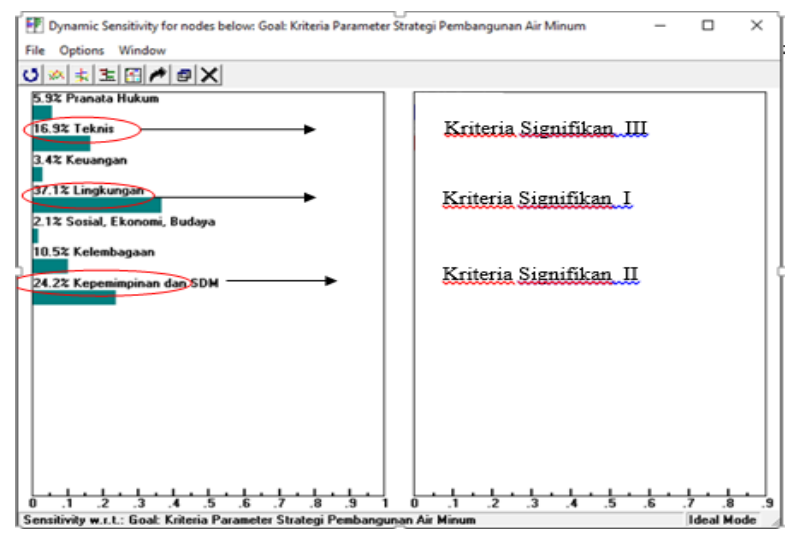

Gambar 3 Tingkat pengaruh parameter kriteria

Diketahui bahwa rasio konsistensi yang diperoleh adalah sebesar 0,08, berarti pendapat tersebut dinyatakan konsisten (lihat lampiran). Analisa kriteriakriteria yang memiliki prioritas (tingkat) palingmempengaruhi dalam strategi pembangunan air minum Kota Dumai yaitu kriteria lingkungan sebesar 37,1\% dari total kriteria yang ada, menyusul kriteria kepemimpinan sebesar 24,2\%, kriteria teknis sebesar 16,9\%.Menurut prinsip Pareto 80 persen hasil dihasilkan dari upaya 20 persen, prinsip ini telah terbukti berlaku di banyak kejadian (Koch,1998). Untuk itu dalam penyusunan strategi pembangunan SPAM di Kota Dumai ini, hanya 3 (tiga) kriteria utama (urutan 1,2 dan 3) sesuai urutan di atas yang digunakan untuk menyusun strategi yaitu kriteria lingkungan, kriteria kepemimpinan dan SDM dan kriteria teknis. Berdasarkan ketiga kriteria utama pembangunan SPAM dikembangkan strategi-strategi pembangunan SPAM di Kota Dumai.

\section{PENENTUAN PRIORITAS STRATEGI}

Survei dilakukan dengan menyebarkan 5 kuesioner kepada 3 instansi yaitu Dinas Pekerjaan Umum Kota Dumai, Dinas Pekerjaan Umum dan Tata Ruang Provinsi Riau, Bappeda Kota Dumai,Tim dan Tenaga Ahli Air Minum Dinas PUPR Kota Dumai.Langkahdalam analisa ini adalah memasukkan strategi-strategi pembangunan SPAM yang telah dihasilkan oleh isian kuisioner ke aplikasi Expert Choice 2000. Hasil dari prioritas strategi pembangunan SPAM Kota Dumai adalah seperti pada gambar 4 berikut: 


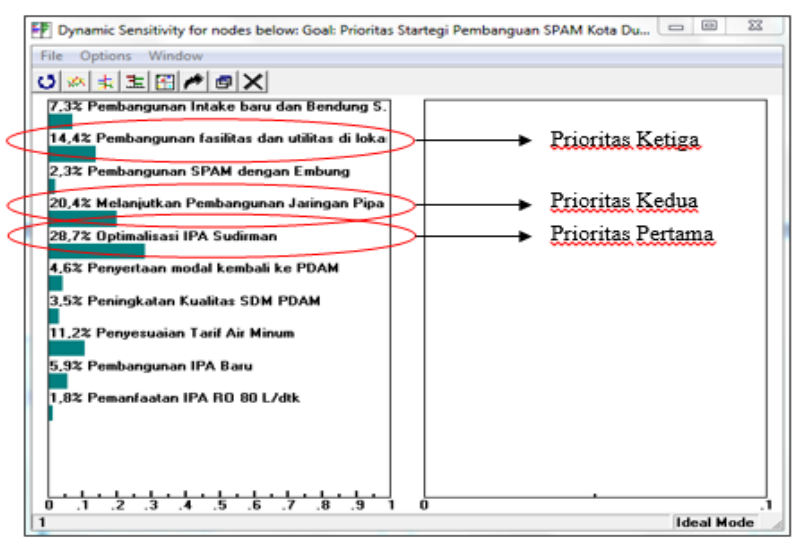

Gambar 4 Tingkat Prioritas Strategi

\section{STRATEGI JANGKA MENENGAH PEMBANGUNAN SPAM KOTA DUMAI}

Setelah didapatkannya urutan dari prioritas strategi pembangunan SPAM Kota Dumai melalui analisa AHP dengan menggunakan expert choice 2000 maka disusun strategitersebut menjadi suatu strategi pembangunan 5 (lima) tahunan atau jangka menengah. Pemilihan jangka menengah ini menyesuaikan dengan Rencana Pembangunan Jangka Menengah Daerah (RPJMD) dengan jangka lima tahun dan juga masa pemerintahan bupati atau wali Kota yang juga lima tahun.Sesuai dengan Undang-undang Nomor 25 tahun 2004 tentang sistim perencanaan pembangunan nasionalyang dimaksud dengan rencana strategis adalah rencana jangka menengah. Strategi pembangunan jangka menengah pembangunan SPAM Kota Dumai bisa dilihat pada tabel 3.

Tabel 3 Strategi Pembangunan SPAM Kota Dumai 2018 - 2023

\begin{tabular}{|c|c|c|c|c|c|c|}
\hline \multirow{2}{*}{ No } & \multirow{2}{*}{ URAIAN } & TAHUN I & TAHUN II & $\overline{\text { TAHUN II }}$ & TAHUN IV & TAHUN V \\
\hline & & 2019 & 2020 & 2021 & 2022 & 2023 \\
\hline 1 & Optimalisasi IPA Sudirman & & & & & \\
\hline 2 & Melanjutkan Pembangunan Jaringan Pĩpa Tahun 2008 - 2011 & & & & & \\
\hline 3 & \begin{tabular}{|l|}
$\begin{array}{l}\text { Pembangunan Fasilitas dan Utilitas di lokasi off Take SPAM } \\
\text { Regional }\end{array}$ \\
\end{tabular} & & & & & \\
\hline 4 & Penyesuaian Tarif Air Minum Berdasarkan Pemulihan Biaya & & & & & \\
\hline 5 & Pembangunan Intake dan Bendung Sungai Mesjid & & & & & \\
\hline 6 & \begin{tabular}{|l|} 
Pembangunan IPA Baru Yang Tepat Guna Sehingga Menghasilkan \\
Harga Yang Sesuai Dengan Daya Jangkau Masyarakat
\end{tabular} & & & & & \\
\hline 7 & Penyertaan Modal Kembali ke PDAM & & & & & \\
\hline 8 & Peningkatan Kualitas SDM PDAM & & & & & \\
\hline 9 & Pembangunan SPAM Embung & & & & & \\
\hline 10 & Pemanfaatan IPA RO 80 L/dtk & & & & & \\
\hline
\end{tabular}

Setelah didapatkannya urutan dari prioritas strategi pembangunan SPAM Kota Dumai melalui analisa AHP dengan menggunakan expert choice 2000 maka disusun strategi tersebut menjadi suatu strategi pembangunan 5 (lima) tahunan atau jangka menengah. Pemilihan jangka menengah ini menyesuaikan dengan Rencana Pembangunan Jangka Menengah Daerah (RPJMD) dengan jangka lima tahun dan juga masa pemerintahan bupati atau wali Kota yang juga lima tahun.Sesuai dengan 
Undang-undang Nomor 25 tahun 2004 tentang sistim perencanaan pembangunan nasionalyang dimaksud dengan rencana strategis adalah rencana jangka menengah. Strategi pembangunan jangka menengah pembangunan SPAM Kota Dumai bisa dilihat pada tabel 3. Struktur hirarki lengkap metoda AHP pada studi penelitian ini bisa dilihat pada gambar 5 .

\section{ANALISA AHP TAHAP ॥}

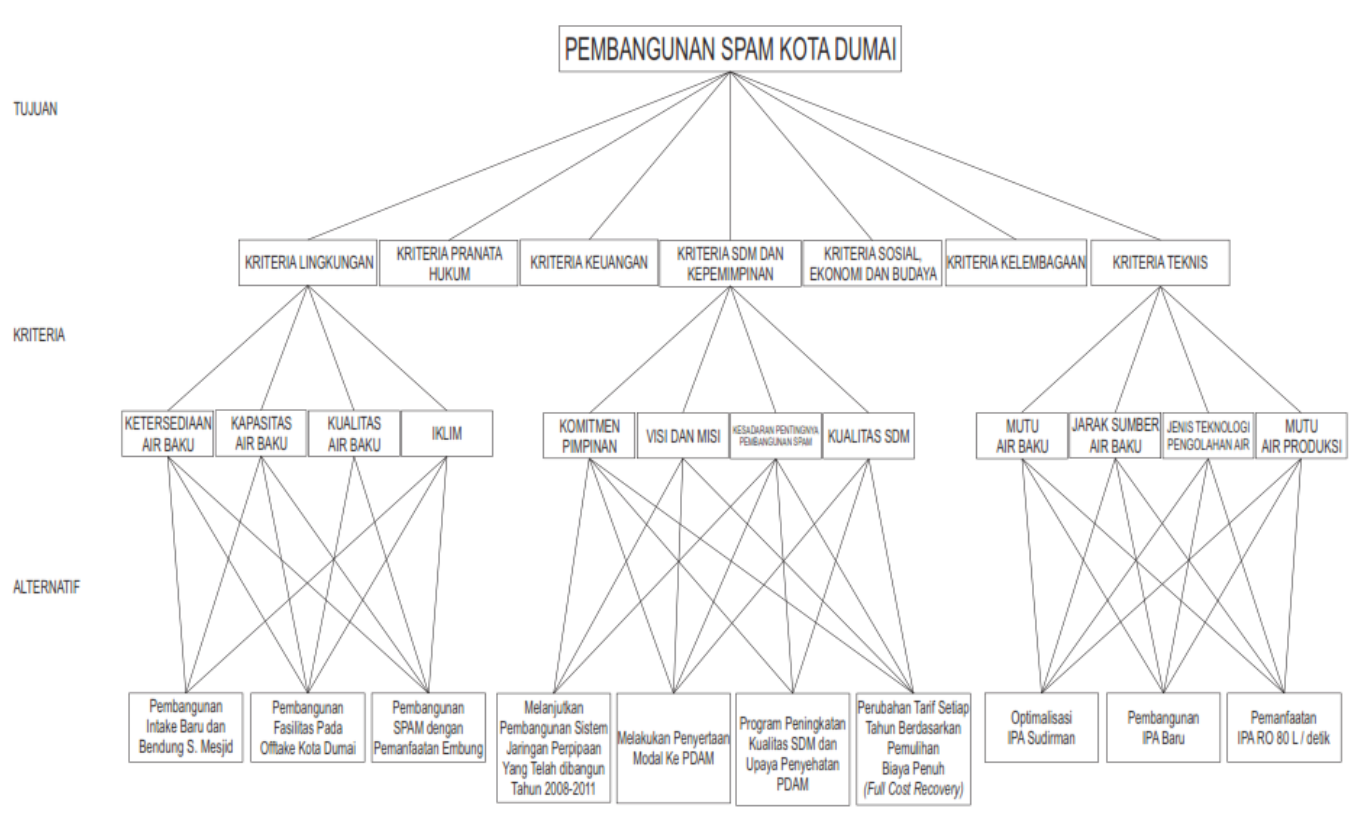

Skema lengkap pembangunan SPAM Kota Dumai selama 5 (lima) dapat dilihat pada Gambar 5

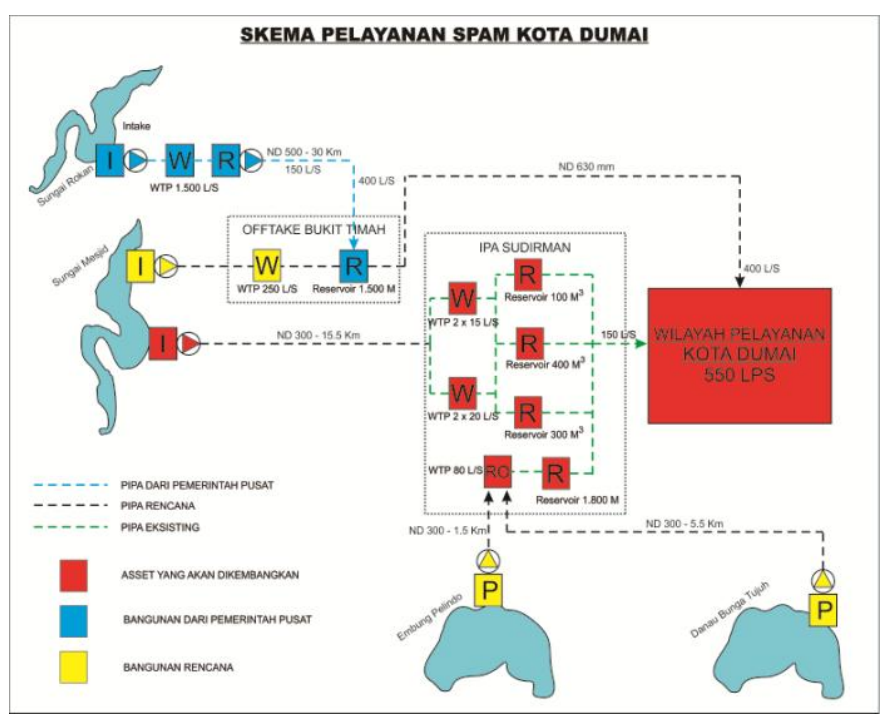

Gambar 5 Skema Pembangunan SPAM Kota Dumai 2018-2023 


\section{KESIMPULAN DAN SARAN}

Penelitian untuk strategi pembangunan SPAM Kota Dumai dengan mengggunakan AHP ini menghasilkan kesimpulan bahwa:

1. Hasil penilaian kesiapan seluruh kriteria pembangunan SPAM di Kota Dumai dihasilkan nilai 2,55 dengan skala kategori III dari skala penilaian I - IV yang berarti kesiapan pembangunanSPAM di Kota Dumai pada kategori siap.

2. Diidentifikasi 7 (tujuh) kriteria signifikan yang mempengaruhi pembangunan SPAM di Kota Dumai adalah kriteria pranata hukum,kriteria teknis, kriteria keuangan,kriteria lingkungan, kriteria sosial ekonomi budaya, kriteria kelembagaan dan terakhirkriteria kepemimpinan dan SDM.

3. Hasil analisa expert choice 2000 dari hasil kuesioner tahap II kriteria-kriteria yang memiliki prioritas (tingkat) paling mempengaruhi dalam strategi pembangunan

4. air minum kota Dumai yaitu kriteria lingkungan sebesar $37,1 \%$, kriteria kepemimpinan dan SDM sebesar $24,2 \%$ serta kriteria teknis sebesar $16,9 \%$.

5. Strategi pembangunan jangka menengah SPAM Kota Dumai terdiri dari sepuluh strategi disusun dalam periode 5 (lima) tahun. Strategi tersebut adalah optimalisasi IPA Sudirman, melanjutkan pembangunan jaringan pipa tahun 2008-2011, pembangunan fasilitas dan utilitas di lokasi off take SPAM Regional, penyesuaian tarif air minum, pembangunan intake dan bendung Sungai Mesjiid, pembangunan IPA baru, penyertaan modal kembali ke PDAM, peningkatan kualitas SDM PDAM, pembangunan SPAM embung dan pemanfaatan IPA RO $80 \mathrm{~L} / \mathrm{dtk}$.

\section{DAFTAR PUSTAKA}

Andani,S. Maryati, 2013. Kriteria Keberhasilan Kerjasama Antar Daerah Dalam Penyediaan Pasokan Air Baku Untuk Perusahaan Daerah Air Minum (PDAM), Jurnal Magister Perencanaan Wilayah dan Kota ITB, Bandung.

Arwin, 2009. Perubahan Iklim, Konversi Lahan dan Ancaman Banjir dan Kekeringan di Kawasan Terbangun. Pidato Guru Besar di Majelis Guru Besar ITB Bandung, disampaikan pada Rapat Majelis Guru Besar ITB, 27 Februari 2009, Bandung

BPPSPAM, 2014. Petunjuk Teknis Evaluasi Kinerja PDAM, Kementrian PU, Jakarta

Budi D. Sinulingga, 1999.Pembangunan Kota Tinjauan Regional dan Lokal, Pustaka Sinar Harapan, Jakarta.

C.D. Soemarto, 1995. Hidrologi Teknik, Usaha Nasional, Surabaya.

Departemen Kesehatan Republik Indonesia, 2004. Peraturan Menteri Kesehatan Nomor 1205/MENKES/PER/X/2004 Tentang Pedoman Persyaratan Kesehatan Pelayanan Sehat Pakai Air (SPA), Jakarta.

Departemen Negara Hukum dan Hak Asasi Manusia, 2005. Peraturan Pemerintah Republik Indonesia Nomor 16 Tahun

2005 Tentang Pengembangan Sistem Penyediaan Air Minum, Jakarta. 
Departemen Negara Hukum dan Hak Asasi Manusia, 2005. Peraturan Pemerintah Republik Indonesia Nomor 82 Tahun 2001 Tentang Pengelolaan Kualitas Air dan Pengendalian Pencemaran Air, Jakarta.

Departemen Permukiman dan Prasarana Wilayah, 1998. Juknis Sistem Penyediaan Air Bersih Kimpraswil, Jakarta.

Departemen Permukiman dan Prasarana Wilayah, 2003. SK Standar Nasional Indonesia Untuk Air Bersih, Jakarta.

Dinas Pekerjaan Umum, 2012. Fs Kajian Ulang Dan Appraisal Pembangunan Infrastruktur Air Minum Kota Dumai, PT. Holistika prima grahita dan PT. U Tekno (kso), Dumai

Dinas Pekerjaan Umum, 2014. Rencana Induk Sistim Penyediaan Air Minum Kota Dumai, PT. Holistika Prima Grahita, Dumai

Dinas PU Kota Dumai, 2011. LAKIP Dinas PU Kota Dumai Tahun 2011. Dinas PU Kota Dumai. Dumai

Dinas PU Kota Dumai, 2016. Rencana Strategis Dinas PU Kota Dumai Tahun 2016, Dumai

Ervianto, W. I. 2003. Manajemen proyek Kontruksi, ANDI, Jogjakarta

Hindarko, S. 2013. Air Bersih untuk Kita Semua. ESHA, Jakarta

Kadarsah, Ramadani, 2000. Sistem pendukung keputusan: Suatu Wacana Struktural Idealisasi dan Implementasi Konsep Pengambilan Keputusan, Remaja Rosdakarya, Bandung.

Kementrian Kesehatan Republik Indonesia, 2002, Keputusan Menteri Kesehatan Republik Indonesia Nomor 1405/MENKES/SK/XI/2002 tentang Persyaratan Kesehatan Lingkungan Kerja Perkantoran dan Industri, Jakarta

Kementrian Kesehatan Republik Indonesia, 2010. Peraturan Menteri Kesehatan Nomor 492/MENKES/PER/IV/2010 Tentang Persyaratan Kualitas Air Minum, Jakarta

Kementrian Perencanaan Pembangunan Nasional/BAPPENAS, 2010. Pedoman Penyusunan Aksi Percepatan Pencapaian Tujuan MDGs di Daerah, Jakarta.

Kementrian Kesehatan Republik Indonesia, 2004.Peraturan Menteri Kesehatan Nomor 1205/MENKES/PER/X/2004 Tentang Pedoman Persyaratan Kesehatan Pelayanan Sehat Pakai Air (SPA), Jakarta

Kodatie, R. J, 2002. Analisis Ekonomi Teknik, ANDI, Jogjakarta.

Marimin. 2004. Teknik Aplikasi Pengambilan Keputusan dalam Kriteria Jamak, Grasindo, Jakarta

N. Hadisusanto. 2011. Aplikasi Hidrologi, Jogja Media Utama, Jogjakarta.

Nur Rochmah Dyah, Armandira Maulana P. 2009. Sistem Pengambilan Keputusan Perencanaan Strategis Kerja Instansi dengan menggunakan AHP, Jurnal Informatika. http;//jogjapress.com/index.php/JIFO/article/view/324. ISSN 19780524 .

Pangeran, Moch. Husnullah. 2006. Identifikasi dan Analisis Dampak Resiko-Resiko Dominan Terhadap Kelayakan Finansial Konsesi Infrastruktur Air Minum, Tesis Magister perencanaan Wilayah dan Kota ITB, Bandung.

Pareto Richard Koch, 1998.The 80/20 Principle: The Secret Of Achieving More Than Less, Double Day, New York

Peraturan Pemerintah Republik Indonesia Nomor 121 Tahun 2015 tentang Pengusahaan Sumber Daya Air.

Peraturan Pemerintah Republik Indonesia Nomor 122 Tahun 2015 tentang Sistem Penyediaan Air Minum.

Prihatin, Rohani Budi, 2013. Problem Air Bersih di Perkotaan, Info Singkat Pusat Pengkajian Pengolahan Data dan Informasi (P3DI) Setjen DPR RI, Jakarta.

Pudjosumanto, Mulyadi. 1998. Evaluas Proyek, Liberty, Jogyakarta 
R. Asih, 2006. Kajian Aspek-Aspek yang Mempengaruhi Penyediaan Air Bersih Secara Individual di Kawasan Kaplingan Kota Blora,Tesis Program Studi Magister Teknik Perencanaan Wilayah dan Kota Universitas Diponegoro, Semarang.

Rahmi. 2013. Identifikasi Parameter Optimalisasi Penggunaan Air Irigasi berdasarkan Analytical Hierarchy Process (AHP), Tugas Akhir Program Teknik Sipil Fakultas Teknik Universitas Riau, Pekanbaru

Saaty, Thomas L. 1993. Decision Making For Leader : The Analytical Process Decision in Complex World, Gramedia, Jakarta

Sabar Arwin. 2009, Trend Pembangunan Infrastruktur Sumber Daya Air Berkelanjutan, Kementrian Perencanaan Pembangunan Nasional/Bappenas, Jakarta.

Sandhyavitri, Ari. 2009. Major Threats and Stategy of Sustainability of Water Suply Industry Operation (Case study In Indonesia), Journal in 34 th WEDC International Conference, Addis Ababa, Ethiopia

Soeharto Iman, 2003. Studi Kelayakan Proyek Industri, Erlangga, Jakarta

Soeharto, Iman. 1999. Manajemen Proyek (dari Konseptual Sampai Operasional), Erlangga, Jakarta

Undang-Undang RI Nomor 11 Tahun 1974 tentang Pengairan

Undang-Undang RI Nomor 23 Tahun 2014 tentang Pemerintah Daerah

Unicef Indonesia, 2012. Air Bersih, Sanitasi dan Kebersihan. Ringkasan Kajian Laporan Unicef Indonesia, Jakarta

Yerimias, Keban. 2007. Kerjasma antar Pemerintah Daerah dalam Era Otonomi : Isu Stratregis , Bentuk dan Prinsip, Jakarta 